\title{
Serological Types of Streptococcus faecalis and its Varieties and their Cell Wall Type Antigen
}

\author{
By M. ELISABETH SHARPE \\ National Institute for Research in Dairying, University of Reading
}

(Received 25 February 1964)

SUMMARY

When serological type strains of Streptococcus faecalis from different workers were compared with those of Sharpe \& Shattock (1952) by using precipitin and reciprocal absorption tests, several of these types were found to possess the same type antigens. The location of these type antigens was in the cell wall and they were polysaccharide in nature. Some strains had two of these antigens. The distribution of $S$. faecalis serotypes is discussed and a typing scheme applicable to all recognized types of group D streptococci is suggested.

\section{INTRODUCTION}

Shattock (1962) showed that the Lancefield group D streptococci could be divided on the basis of their physiological characteristics into three subdivisions consisting of: (i) Streptococcus faecalis and its varieties zymogenes and liquefaciens; (ii) $S$. faecium and $S$. durans; (iii) $S$. bovis and $S$. equinus. These broad divisions were also supported by serological evidence, as type antigens occurring in the strains within each subdivision are distinct from those found in strains within the other subdivisions (Skadhauge, 1950; Sharpe \& Shattock, 1952; Sharpe \& Fewins, 1960; Medrek \& Barnes, 1962).

Within the subdivision Streptococcus faecalis (this term is used here to include the varieties $S$. faecalis var. zymogenes and $S$. faecalis var. liquefaciens) of group D streptococci a number of serological types have been defined. Lancefield's original group D streptococci included 3 strains of $S$. faecalis each having a different type antigen (Lancefield, 1941). Grumbach (1943) used agglutination and precipitin typing to define 21 serological types of enterococci, but did not include sufficient physiological tests to subdivide these organisms further. Later Skadhauge (1950) divided $S$. faecalis strains into 6 groups, based on the presence of thermostable ' $O$ ' agglutinins; Sharpe \& Shattock (1952) differentiated by agglutination and precipitin tests 9 serological types of $S$. faecalis, 2 of which appeared to be homologous with 2 of the original Lancefield strains, and Elliott (1957) and Elliott \& Barnes (1959) have distinguished by precipitin typing 2 further serological types, one of which they thought to be the same as one of the Sharpe \& Shattock types. They also found that the third Lancefield type, which had not previously been available for comparison, was the same as another of the Sharpe \& Shattock types.

Since group D streptococci are of importance as indicators of faecal pollution, as agents of food spoilage, as possible pathogens, and as components of the normal intestinal flora concerned in nutrition, their serological identification may sometimes 
be necessary. It has been suggested that in order to prevent replication of types and to provide a common reference, a serological typing scheme should be recommended for use by workers in this field. As Elliott (1960) found the type specific antigens of 3 strains of Streptococcus faecalis and 1 of $S$. durans to be cell wall polysaccharide, it has been suggested by Lancefield, quoted in the report of the International Sub-committee on Streptococci and Pneumococci (1963) that the serological subdivision of group $\mathbf{D}$ should be based on the precipitin reactions of numbered antigens, these antigens being cell wall polysaccharides. The work reported here describes a comparison of the $S$. faecalis serological types of different workers, and the location of their specific cell wall type antigens. The ability of periodate to inactivate cell wall antigens was used as an indication of their carbohydrate nature. Similar work has been undertaken with the type antigens of $S$. faecium by Dr E. M. Barnes, Low Temperature Research Station, Cambridge.

\section{METHODS}

Strains of Streptococcus faecalis examined. The three original Lancefield (1941) strains, the 9 type strains of Sharpe \& Shattock (1952), the 2 Elliott (1957) types and 18 strains from Skadhauge, representing his 6 ' $O$ ' groups, were investigated. In addition all of the 21 Grumbach (1943) type strains of enterococci were obtained from the Streptococcal Reference Laboratory (Colindale, London, N.W.9), and their physiological characteristics examined to amplify the previous description, by using most of the tests described by Shattock (1962). A sufficient number of physiological characteristics of the other strains used in this work were examined to confirm their identity as $S$. faecalis. Strains were cultured in $1.0 \%(\mathrm{w} / \mathrm{v})$ glucose nutrient broth and were maintained in glucose litmus milk + chalk. Lyophilized cultures grown in GLB were used for the production of antisera.

Preparation of group antisera. The method of Shattock (1949) was used, the cells being disrupted in the Mickle tissue disintegrator.

Preparation of type antisera. Type antisera were prepared against the 3 Lancefield types, the 9 Sharpe \& Shattock types and the 2 Elliott types, and were absorbed if necessary to make them specific (Sharpe \& Fewins, 1960).

$\mathrm{HCl}$ extracts of whole organisms. HCl extracts (Lancefield, 1933) were prepared as described by Sharpe \& Shattock (1952) using the growth from $40 \mathrm{ml}$. glucose nutrient broth, except that cultures were incubated for $18 \mathrm{hr}$ at $22^{\circ}$ instead of at $30^{\circ}$ (Sharpe \& Fewins, 1960).

Precipitin ring tests. Jones \& Shattock (1960). Extracts were layered over sera and examined at intervals up to $\mathbf{3 0} \mathrm{min}$.

Crude cell walls. Using the method of Elliott (1960) strains were grown for $24 \mathrm{hr}$ at $22^{\circ}$ in $500 \mathrm{ml}$. of $0.5 \%(\mathrm{w} / \mathrm{v})$ glucose nutrient broth, washed twice in sterile distilled water, suspended in $6 \mathrm{ml}$. distilled water $+4 \mathrm{~g}$. Ballotini beads No. 12 and treated on the Mickle tissue disintegrator in the cold for $1 \frac{1}{2} \mathrm{hr}$ or until a microscopic examination revealed that all the cocci had been disrupted. The beads and any undisrupted cocci were removed by slow centrifugation, and the cell walls separated from the cell contents by centrifuging at $4800 \mathrm{rev} . / \mathrm{min}$. and washed with distilled water.

$\mathrm{HCl}$ extracts of cell walls. Extracts were prepared by the same method as used for whole organisms. 
Lysozyme extracts. Cell walls were suspended in $3 \mathrm{ml}$. of $0.05 \mathrm{M}-$ phosphate buffer (pH 6.2) and incubated with crystalline egg white lysozyme (Armour) in a concentration of $1.0 \mathrm{mg} . / \mathrm{ml}$. for $3 \mathrm{hr}$ at $37^{\circ}$, and then overnight if no clearing had occurred. The suspension was then adjusted to $\mathrm{pH} 7 \cdot 6$ with $\mathrm{N}-\mathrm{NaOH}$ and the preparation centrifuged to removed undigested cell debris.

Trypsin digestion. Crystalline trypsin $(1 \mathrm{mg} . / \mathrm{ml}$.) was added to the lysed cell walls, and digestion allowed to proceed for $3 \mathrm{hr}$ at $37^{\circ}$ at $\mathrm{pH} 6 \cdot 2$; then adjusted to $\mathrm{pH} 7 \cdot 0$.

Further purification of antigens (Elliott, 1960). By ethanol precipitation (2 vol. antigen preparation:5 vol. ethanol), an ethanol-soluble fraction and an ethanolinsoluble fraction were separated. The ethanol-soluble fraction was taken up in acetone ( 5 times the original volume) and then redissolved in water.

Periodate test for carbohydrate on partially purified cell wall preparations. (a) By the method of Bobbitt (1956). To $1.0 \mathrm{ml}$. of the acetone precipitated fraction of cell walls, $1.0 \mathrm{ml}$. of $0.04 \mathrm{M}$-sodium periodate in $0.4 \mathrm{M}-\mathrm{Na}$ acetate buffer $(\mathrm{pH} 4.0$ ) was added. After leaving for $1-1 \frac{1}{2} \mathrm{hr}$ in the dark at room temperature $0.1 \mathrm{ml}$. of $5.0 \%$ $(\mathrm{v} / \mathrm{v})$ ethylene glycol in water was added to destroy the periodate and the solution was adjusted with $\mathrm{N}-\mathrm{NaOH}$ to $\mathrm{pH} \mathbf{7 \cdot 0}$. Appropriate controls with distilled water instead of antigen, and also with antigen added after the periodate had been destroyed and adjusted to $\mathrm{pH} \mathbf{7 \cdot 0}$, were also included. (b) By the method of Elliott (1960). One ml. of antigen $+1.0 \mathrm{ml}$. of $0.002 \mathrm{M}$-sodium periodate solution were incubated at $37^{\circ}$ for $4 \mathrm{hr}$. Periodate-treated cell wall extracts were then tested against the homologous type antisera.

\section{RESULTS}

\section{Serological types}

By using specific type antisera and $\mathrm{HCl}$ extracts of whole organisms, it was confirmed by reciprocal absorption tests that the three Lancefield types were homologous with 3 of the 9 Sharpe \& Shattock types, namely 1, 3 and 4, whilst the 2 Elliott types did not correspond to any types previously described. Eleven serologically distinct precipitin antigens were thus differentiated (Table 1). When $\mathrm{HCl}$ extracts of the Skadhauge strains were tested against these 11 antisera, it was found that the Skadhauge ' $O$ ' groups, defined by agglutination tests, did not correspond exactly to the serological types defined by other workers using the precipitin test. However, the different Skadhauge strains representing each group are identified by a strain number (Table 1) so that the specific reactions of these numbered strains can be related to the serological types of other workers and Skadhauge's results correlated with theirs. Of the 21 Grumbach type strains 5 were Streptococcus faecalis. Skadhauge's Group II contained two of the Sharpe \& Shattock types, whilst some of his strains were shown by absorption to possess two of the type precipitin antigens recognized by these workers (Table 2). The remainder were identified as $S$. faecium, $S$. durans or were unclassified. Of the $5 S$. faecalis strains the proteolytic properties of 2 strains and the haemolytic activity of 2 other strains did not correspond to those of the original description. In addition 3 strains identified here as $S$. faecium had been identified previously by Skadhauge (1950) as $S$. faecalis. The serological reactions of extracts of the Grumbach strains with the Sharpe \& Shattock 
type antisera were as follows: 1 and 4 reacted with antiserum type 6,3 reacted with antiserum type 9, 24 with antiserum type 3 , and 5 did not react with any of the Sharpe \& Shattock type antisera. In view of the uncertainty of the identity of the strains with those originally described, no further work was done with them.

Table 1. Serological types of Streptococcus faecalis designated by different workers and found to possess homologous type antigens by reciprocal absorption tests

\begin{tabular}{|c|c|c|c|}
\hline $\begin{array}{c}\text { Sharpe \& Shattock (1952) } \\
\text { Serological type }\end{array}$ & Lancefield (1941) & Elliott (1957) & Skadhauge (1950 \\
\hline 1 & D 76 & . & Group I (503)* \\
\hline $\mathbf{3}$ & н 69 D 5 & . & Group VI (120) \\
\hline 4 & c 1 & . & \\
\hline $\mathbf{5}$ & • & . & Group II (50) \\
\hline 6 & . & . & Group IV (782) \\
\hline 8 & . & . & 7. \\
\hline 9 & . & . & Group III (3) \\
\hline 19 & . & . & Group II (783) \\
\hline 20 & . & - & . \\
\hline . & . & D 10 & . \\
\hline . & 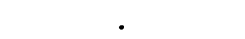 & D 15 & . \\
\hline
\end{tabular}

Table 2. Precipitin reactions of $\mathrm{HCl}$ extracts of Skadhauge's strains of group $D$ streptococci, previously differentiated into groups by their ' $O$ ' agglutinins

\begin{tabular}{|c|c|c|c|c|c|c|c|c|c|}
\hline \multirow{2}{*}{$\begin{array}{l}\text { Skadhauge } \\
\text { 'O' group }\end{array}$} & \multirow{2}{*}{$\begin{array}{c}\text { Strains } \\
\text { (Skadhauge numbers) }\end{array}$} & \multicolumn{8}{|c|}{ Reaction with specific antisera type } \\
\hline & & 1 & 5 & 19 & 9 & D 15 & $\mathbf{3}$ & 6 & $\begin{array}{l}4,5,8 \\
\text { D } 10\end{array}$ \\
\hline $\mathbf{I}$ & $\begin{array}{l}28,44,46,52,438 \\
503,520\end{array}$ & + & - & - & - & - & - & - & - \\
\hline II & $\begin{array}{l}\text { 50, 53, } \\
\mathbf{3 3 5} \\
\mathbf{3 7 7}\end{array}$ & $\begin{array}{l}- \\
-\end{array}$ & $\begin{array}{l}+ \\
+\end{array}$ & $\begin{array}{l}+ \\
+ \\
-\end{array}$ & $\begin{array}{l}- \\
-\end{array}$ & $\begin{array}{l}- \\
-\end{array}$ & - & - & $\begin{array}{l}- \\
- \\
-\end{array}$ \\
\hline III & $\begin{array}{l}3,75 \\
58\end{array}$ & - & $\overline{-}$ & $\begin{array}{l}- \\
-\end{array}$ & $\begin{array}{l}+ \\
+\end{array}$ & $\overline{+}$ & $\begin{array}{l}- \\
-\end{array}$ & - & $\begin{array}{l}- \\
-\end{array}$ \\
\hline IV & 782 & - & - & - & - & - & - & + & - \\
\hline $\mathbf{V}$ & 567 & - & - & - & - & - & - & - & - \\
\hline VI & 120 & - & - & - & - & - & + & - & - \\
\hline
\end{tabular}

\section{Cell wall antigens}

Cell wall preparations of the 3 Lancefield serological type strains, the 9 Sharpe $\&$ Shattock types, 2 Elliott types and 8 of the Skadhauge strains were examined.

$\mathrm{HCl}$ extracts of cell walls. When $\mathrm{HCl}$ extracts of cell walls of several different type strains were made, they gave no type reactions although $\mathbf{H C l}$ extracts of whole organisms and lysozyme extracts of cell walls of the same strains gave strong type precipitin reactions. It was found that at $100^{\circ}$ the antigen in the cell wall was more sensitive to $\mathrm{pH} 1.5$ (produced by the addition of $0.05 \mathrm{~N}-\mathrm{HCl}$ ) than when it was in the whole cell. When adjusted to $\mathrm{pH} 2 \cdot 0$ (Table 3) the antigen was not destroyed. A specific reaction then occurred between cell wall extract and antiserum, each 
type strain reacting with its homologous antiserum. Elliott (1960) found that the type antigen was destroyed by heating to $100^{\circ}$ for $10 \mathrm{~min}$. at $\mathrm{pH} 1 \cdot 0$, but not at pH 2.0.

Table 3. Precipitin reactions of $\mathrm{HCl}$ extracts of whole cells and cell walls of strain $\mathrm{N} 37$ (type 1) heated to $100^{\circ}$ at different $\mathrm{pHs}$ for different times

$\begin{array}{lccc}\text { Material } & \begin{array}{c}\text { Length of time } \\ \text { extracted heated to } \\ 100^{\circ} \text { (min.) }\end{array} & \begin{array}{c}\mathrm{pH} \text { during heat } \\ \text { treatment }\end{array} & \begin{array}{c}\text { Precipitin reaction of } \\ \text { extract with } \\ \text { homologous type } \\ \text { antiserum }\end{array} \\ \text { Cell walls } & 3 & 1 \cdot 3 & ++ \\ & 5 & 1 \cdot 5 & ++ \\ \text { Whole cocci } & 10 & 1 \cdot 5 & + \\ \text { Cell walls } & 20 & 1 \cdot 45 & + \\ & 20 & 1 \cdot 4 & ++ \\ & 3 & 2 \cdot 0 & ++ \\ & 5 & 2 \cdot 05 & ++ \\ \text { Whole cocci } & 10 & \mathbf{2 \cdot 0} & ++ \\ & 20 & 2 \cdot 0 & ++\end{array}$

++ , Strong precipitin reaction within $1 \mathrm{~min} . ;+$, moderate precipitin reaction within 5 min.; -, no precipitin reaction within 20 min.

\section{Lysozyme extracts of cell walls and further treatment and purification}

Table 4 shows the precipitin reactions of cell walls, after treatment with lysozyme and with trypsin, and of the ethanol- and acetone-precipitated fractions. In some cases no serological reaction was observed with the acetone-precipitated fraction although a very strong reaction occurred with the ethanol-precipitated one. On reprecipitating the latter fraction with acetone the precipitate obtained was serologically active and it was assumed, as suggested by Dr S. D. Elliott (personal communication) that the type specific material must all have become entrained in the first instance with the original very heavy ethanol precipitate. The lysed cell walls of each of the 22 strains reacted strongly with the specific antiserum, confirming Elliott's (1960) observations with 3 strains of Streptococcus faecalis that the type antigen of this organism was situated in the cell wall. Cell contents, separated from the cell walls by centrifugation, in addition to reacting with group $\mathbf{D}$ antiserum also reacted with the type antisera, probably because some parts of the cell walls had been disrupted into very small fragments which had not been removed by centrifugation.

Treatment with trypsin did not destroy the type antigens, suggesting that they are unlikely to be protein. Treatment of the cell walls with lysozyme followed by the addition of dilute $\mathrm{NaOH}$ drop by drop did not always result in clearing. Sometimes the preparation remained cloudy, at others it was cleared completely. This was found to be associated with the age of the culture and temperature of incubation. When a comparison was made between cultures of strain N37 grown in glucose nutrient broth and incubated for 18 or $48 \mathrm{hr}$ at $37^{\circ}$ with cultures incubated at $22^{\circ}$, the cultures grown at $37^{\circ}$ remained cloudy, whilst those at $22^{\circ}$ were completely cleared; an 8-hr culture incubated at $37^{\circ}$ also showed complete clearing. However, 
precipitin tests, using 10-fold serial dilutions of antigens, showed no difference in the reacting titre of the type antigen released (Table 5). Cell wall components not lysed by lysozyme are present after incubation for $18 \mathrm{hr}$ at $37^{\circ}$ but not after $8 \mathrm{hr}$, whilst even after incubation for $48 \mathrm{hr}$ at $22^{\circ}$ lysozyme-resistant components were not present. This was not due to the state of growth of the organisms either in the logarithmic or stationary state; counts of viable organisms at intervals up to $72 \mathrm{hr}$ showed that with cultures incubated at $37^{\circ}$ the logarithmic phase of growth occurred

Table 4. Precipitin reactions of cell wall extracts of serological types of group $D$ streptococci

\begin{tabular}{|c|c|c|c|c|c|c|}
\hline & ecipitin & $\begin{array}{l}\text { actions aga } \\
\text { wall extracts }\end{array}$ & $\begin{array}{l}\text { st type a } \\
\text { fter treat }\end{array}$ & $\begin{array}{l}\text { era of cell } \\
\text { tt }\end{array}$ & & \\
\hline Type and strain & $\begin{array}{l}\text { digested } \\
\text { with } \\
\text { lysozyme } \\
=(1)\end{array}$ & $\begin{array}{l}\text { (1) digested } \\
\text { with } \\
\text { trypsin } \\
=(2)\end{array}$ & \begin{tabular}{l}
\multicolumn{1}{c|}{ ЕtOH } \\
precipitate \\
of $(2)=(3)$
\end{tabular} & $\begin{array}{c}\text { Acetone } \\
\text { precipitate } \\
\text { after } \\
\text { removal of } \\
(3)=(4)\end{array}$ & $\begin{array}{c}\text { Type } \\
\text { antisera } \\
\text { tested } \\
\text { against }\end{array}$ & $\begin{array}{l}\text { Precipitin } \\
\text { reaction of } \\
\text { (4) against } \\
\text { group } \\
\text { antiserum }\end{array}$ \\
\hline 1, N 37 & + & + & + & + & 1 & - \\
\hline D76 & + & + & + & + & 1 & - \\
\hline 3, н 69 р 5 & + & + & + & + & 3 & - \\
\hline s 161 & + & + & + & + & 3 & - \\
\hline $4, \mathrm{C} 1$ & + & + & + & + & 4 & - \\
\hline GB 122 & + & + & + & + & 4 & - \\
\hline $5, \mathrm{~N} 83$ & + & + & + & + & 5 & - \\
\hline 6, в 65 & + & + & + & + & 6 & - \\
\hline 8,1 AS & + & + & + & $+^{*}$ & 8 & - \\
\hline 9, N 97 & + & + & + & + & 9 & - \\
\hline 19, р 36 & + & + & + & + & 19 & - \\
\hline $20, \mathbf{N} 161$ & + & + & + & + & 20 & - \\
\hline Skadhauge strain & & & & & & \\
\hline Group I, 28 & + & + & + & + & 1 & - \\
\hline Group II, 50 & + & + & \pm & \pm & 5 and 19 & - \\
\hline 335 & + & + & + & \pm & 19 & - \\
\hline 783 & + & + & + & $\bar{t}$ & 5 and 19 & - \\
\hline Group III, 3 & + & + & + & $+*$ & 9 & - \\
\hline 58 & + & + & + & $+*$ & 9 and $\mathrm{D} 15$ & - \\
\hline Group IV, 782 & + & + & + & $+*$ & $\mathbf{3}$ & - \\
\hline Group VI, 120 & + & + & + & $+*$ & 6 & - \\
\hline
\end{tabular}

+ , Reaction to the full titre that had been observed with extract $(1)$; \pm , reaction to the 1/10 titre that had been observed with extract (1).

* No reaction with acetone precipitated fraction but on reprecipitating the EtOHinsoluble fraction with acetone a precipitin reaction was obtained.

within the first 6 to $12 \mathrm{hr}$, but after this time the numbers were the same at both incubation temperatures, remaining stationary for $60 \mathrm{hr}$ and then decreasing. Smith (1963) observed that with whole organisms of group D streptococci lysis was usually complete in less than $3 \mathrm{hr}$, and that it was more rapid in the log phase than in the stationary phase; Douglas \& Parker (1958) found that vegetative cells of Bacillus megaterium were more susceptible to lysozyme when in the exponential phase, than were older cultures. 


\section{Effect of periodate treatment on type antigens}

When the acetone-precipitated cell wall preparations of the 22 strains of Streptococcus faecalis listed in Table 4 were treated with periodate, complete inactivation of the specific type reaction resulted in each case when Bobbitt's (1956) method $(a)$ above, was used. With the Skadhauge strains which appeared to contain two type antigens, both antigens were inactivated by this treatment. By using Elliott's (1960) method $(b)$ above, similar results were obtained except that with the preparations from 5 strains (type 9, type 19, Skadhauge 3, 28, 335) the type precipitin reaction was greatly diminished but not completely destroyed.

Table 5. The effect of time and temperature of incubation of a culture of $\mathrm{N} 37$ (type 1) on the lytic effect of lysozyme on the cell walls

\begin{tabular}{|c|c|c|c|c|c|c|c|}
\hline \multirow{2}{*}{$\begin{array}{c}\text { Experiment } \\
\text { no. }\end{array}$} & \multirow{2}{*}{\multicolumn{2}{|c|}{$\begin{array}{l}\text { Conditions of growth } \\
\text { in glucose nutrient broth } \\
\text { Time (hr) Temp. }\left({ }^{\circ} \mathrm{C}\right)\end{array}$}} & \multirow{2}{*}{$\begin{array}{l}\text { Effect of lysozyme } \\
\text { on the cell wall } \\
\text { suspension }\end{array}$} & \multicolumn{4}{|c|}{$\begin{array}{l}\text { Precipitin reaction of lysozyme- } \\
\text { treated cell walls or controls* with } \\
\text { homologous type antiserum. } \\
\text { Dilution of cell wall preparation }\end{array}$} \\
\hline & & & & $10^{-1}$ & $10^{-2}$ & $10^{-3}$ & $10^{-4}$ \\
\hline 1 & $\begin{array}{l}18 \\
18\end{array}$ & $\begin{array}{l}37 \\
22\end{array}$ & $\begin{array}{l}\text { Slight lysis } \\
\text { Complete lysis }\end{array}$ & $\begin{array}{l}++ \\
++\end{array}$ & $\begin{array}{l}+ \\
+\end{array}$ & $\begin{array}{l} \pm \\
\pm\end{array}$ & - \\
\hline 2 & $\begin{array}{l}48 \\
48\end{array}$ & $\begin{array}{l}37 \\
22\end{array}$ & $\begin{array}{l}\text { No lysis } \\
\text { Complete lysis }\end{array}$ & $\begin{array}{l}++ \\
++\end{array}$ & $\begin{array}{l}+ \\
+\end{array}$ & $\begin{array}{l} \pm \\
\pm\end{array}$ & - \\
\hline 3 & 8 & 37 & Complete lysis & ++ & + & - & - \\
\hline 4 & 24 & 37 & Slight lysis & ++ & ++ & + & - \\
\hline Control* & 24 & $\mathbf{3 7}$ & - & $+t$ & - & - & - \\
\hline $\mathbf{5}$ & 48 & 37 & No lysis & ++ & ++ & + & - \\
\hline Control* & $\begin{array}{l}48 \\
48\end{array}$ & $\begin{array}{l}37 \\
22\end{array}$ & Complete lysis & $\begin{array}{l}++ \\
++\end{array}$ & $\begin{array}{c}+ \\
++\end{array}$ & $\overline{+}$ & - \\
\hline Control* & 22 & 22 & - & ++ & - & - & - \\
\hline
\end{tabular}

* Control = cell walls suspended in phosphate buffer at pH $6 \cdot 2$, without added lysozyme, and incubated for the same time and at the same temperature as the lysozyme treated cell walls. No lysis occurred on any occasion.

++ , Strong precipitin reaction in $1 \mathrm{~min} . ;+$, moderate precipitin reaction in 5 min.; \pm , weak precipitin reaction in 20 min.

\section{Antisera to cell walls}

During this work an attempt was made to prepare a type antiserum against cell walls. Inoculation of a rabbit with a crude cell wall preparation of strain $\mathbf{D} 76$ resulted in a non-type-specific serum which reacted with $\mathrm{HCl}$ extracts of other types of Streptococcus faecalis and with only a moderately strong type reaction. On continued immunization of the rabbit the type reaction became even weaker.

\section{DISCUSSION}

Table 6 shows the distribution of serological types of Streptococcus faecalis, group D, isolated from different materials. In order to compare the data, the type numbers of Sharpe \& Shattock have been used throughout, although both Lancefield (1941) and Wheeler \& Foley $(1945 a, b)$ used the Lancefield strains to prepare their antisera and Skadhauge used his own strains. The same serological types have been reported over a period of years, from different habitats, both animal and 
human, in healthy and pathological material and in different countries. In most of the work quoted here only a small number of strains were not typed, and the evidence strongly suggests that only a limited number of serological types of $S$. faecalis are likely to occur. There is at least one more serological type, as Skadhauge's group V strain did not react with any of the type antisera and therefore must possess a different type antigen.

Table 6. Serological types of Streptococcus faecalis, and its varieties isolated by different workers
Reference
Source of strains
Serological types identified

Lancefield (1941)
Grumbach (1943)
Wheeler \& Foley
$(1945 a)$

Wheeler \& Foley
(1945b)
Skadhauge (1950)
Sharpe \& Shattock
(1952)
Elliott (1957)
Barnes, Sharpe \&
Fewins (1958)
Elliott \& Barnes
(1959)
Sharpe*
Franklin \& Sharpe*
Maxted \& Frazer
(private commun-
ication)

Vagina, U.K.

Cheese, human faeces, U.S.A.

Human faeces, vagina, Germany

Rectum and throat, healthy and sick

infants

Adult throat, urine, tonsillitis

Post-mortem blood, lungs

Subacute endocarditis, U.S.A.

\}U.S.A. 1, 3, 4

Appendices, blood, faeces, urine, Denmark 1, 3, 5, 6, 9, 19

Faeces, healthy and sick infants, U.K.

$1,3,4,5,6,8,9,19,20$

Bovine endocarditis, U.K.

40 (strain D 10)

Healthy adult faeces, U.K.

41 (strain D 15)

Chicken intestine, U.K.

$1,4,40,41$

Human endocarditis, U.K.

Milk, U.K.

Urine, wounds, dental specimens, blood

culture, faeces, U.K.

* Unpublished data.
$1,3,4,41$

1

$1,9,41$

$1,3,4,5,6,9,19$

Examination of 20 strains of Streptococcus faecalis belonging to 11 different serological types shows that the type antigen is situated in the cell wall. It is unaffected by trypsin but inactivated by periodate; this suggests that the antigenic determinants contain sugars and/or sugar alcohols and are unlikely to be protein, although they might be teichoic acids. This confirms Elliott's findings with 3 strains of this species belonging to different serological types. These specific cell wall antigens can thus be used to designate the different serological types. It has been agreed by the International Committee on Bacteriological Nomenclature (1963) to retain the numbers of Sharpe \& Shattock as the cell wall types and to number new types of group D streptococci serially as they arise, following those already designated. It was stressed by Lancefield in the report of the International Subcommittee on Streptococci and Pneumococci (1963) that the serological system of classifying strains of group D streptococci should be independent of their physiological properties and should be kept on a serological basis with chemically defined 
type-specific antigens. This would allow for the possibility of other kinds of typespecific substances which might be discovered later and be differently located.

Table 7 shows the numbering of the cell wall polysaccharide type antigens of Streptococcus faecalis so far designated. The Lancefield strains D76, H69 D5 and c1 replace the Sharpe \& Shattock type strains N37, s161 and GB 122 in types 1, 3 and 4, respectively, as they have prior designation. The Elliott type strains $D 10$ and D15 are also incorporated in this scheme. They are numbered cell wall types 40 and 41 as the Sharpe \& Fewins types of $S$. faecium which are consecutive to the numbers of the Sharpe \& Shattock types extended to type 39. Further cell wall types based on cell wall polysaccharide antigens will continue from this.

Table 7. Numerical series of cell roall polysaccharide type antigens of Streptococcus faecalis and the representative type strains containing these antigens

$\begin{array}{cccc}\begin{array}{c}\text { Cell wall } \\ \text { type no. }\end{array} & \text { Type strain } & \begin{array}{c}\text { Cell wall } \\ \text { type no. }\end{array} & \text { Type strain } \\ 1 & \text { D 76 } & 9 & \text { N 97 } \\ 3 & \text { H69 D5 } & 19 & \text { D 36 } \\ 4 & \text { C1 } & 20 & \text { N 161 } \\ 5 & \text { N 83 } & 40 & \text { D 10 } \\ 6 & \text { B65 } & 41 & \text { D 15 } \\ 8 & \text { 1 AS } & & \end{array}$

In certain strains examined two cell wall type-antigens were found (Table 2), both being polysaccharides and each being common to a different serological type. These can be designated very conveniently by the above system. Skadhauge strains 50 and 53 will be cell wall type 5/19, and strain 58 will be cell wall type 9/41. In this way the antigenic components of these strains or any others which have more than one such type antigen are readily described. It is possible that some of the type strains designated here may possess more than one cell wall polysaccharide antigen which would only become evident if strains having only the single different antigens were found. This system of numbering provides for this contingency.

The destruction of the active antigenic groups of the cell wall type antigens by periodate observed here are in agreement with Elliott's (1960) findings. Cummins \& Slade (1962) however, by using agglutination tests, found that whilst the cell wall of a strain of Streptococcus faecalis was not agglutinated by its homologous antiserum after periodate treatment, cell walls of a strain of $S$. liquefaciens and of $S$. zymogenes were still agglutinated by their homologous antisera after such treatment. These two varieties of $S$. faecalis are closely related to $S$. faecalis on the basis of their physiological characteristics (Shattock, 1962), differing from the latter only in their proteolytic activity and in the ability of $S$. zymogenes to produce $\beta$-haemolysis on horse blood agar. As the type antigens of strains within this species are shared among the 3 varieties, it is somewhat unexpected to find that one strain possesses a periodate-sensitive antigen whilst two possess antigens insensitive to the oxidative effect of periodate. However, the antigens revealed by agglutination tests may not be the same as those type antigens participating in the precipitin test, which are oxidized by periodate. 
The author wishes to thank Dr R. C. Lancefield, Dr S. D. Elliott and Dr R. A. Gibbons for helpful discussions on this work; also Mr K. J. Scott for technical assistance.

All strains used in this work have been deposited with the National Collection of Dairy Organisms.

\section{REFERENCES}

Barnes, E. M., Sharpe, M. E. \& Fewins, B. G. (1958). The significance of faecal streptococci in meat and poultry. VIIth Int. Congr. Microbiol., Stockholm.

Bobiitт, J. M. (1956). Periodate oxidation of carbohydrates. Adv. Carbohyd. Chem. $11,1$. Cummins, C. S. \& SLADE, H. D. (1962). Effect of periodate on cell wall antigens of streptococci. Proc. Soc. exp. Biol., N.Y. 8, 360.

Douglas, H. W. \& PARker, F. (1958). Electrophoretic studies on bacteria. 3. The growth cycle of Bacillus megaterium, the behaviour of cells and the changes produced by lysozyme. Biochem. J. 68, 99.

Eluiott, S. D. (1957). Bacterial endocarditis of cattle. Vet. Rec. 69, 1203.

Elliotr, S. D. (1959). Group and type-specific polysaccharides of group D streptococci. Nature, Lond. 184, 1342.

Eufiott, S. D. (1960). Type and group polysaccharides of group D streptococci. J. exp. Med. 111, 621.

Elliott, S. D. \& Barnes, E. M. (1959). Changes in serological type and antibiotic resistance of Lancefield group D streptococci in chickens receiving dietary chlortetracycline. J. gen. Microbiol. 20, 426.

Int. Bull. bact. Nomenclature (1963). Sub-committee on the taxonomy of the streptococci and pneumococci, 13, 111.

Grumbach, A. (1943). Enterokokkentypisierung. Schweiz. Z. Path. 6, 66.

Jones, D. \& Shatrock, P. M. F. (1960). The location of the group antigen of group D streptococcus. J. gen. Microbiol. 23, 335.

LANCEFIELD, R. C. (1933). A serological differentiation of human and other groups of streptococci. J. exp. Med. 57, 571.

LANCEFIELD, R. C. (1941). Specific relationship of cell composition to biological activity of hemolytic streptococci. Harvey Lect. 36, 251.

MedreK, T. F. \& Barnes, E. M. (1962). The physiological and serological properties of Streptococcus bovis and related organisms isolated from cattle and sheep. J. appl. Bact. $25,169$.

Sharpe, M. E. (1952). Group D streptococci in the faeces of healthy infants and of infants with neonatal diarrhoea. J. Hyg., Camb. 50, 209.

Sharpe, M. E. \& Fewins, B. G. (1960). Serological typing of strains of Str. faecium and unclassified group D streptococci isolated from canned hams and pig intestines. J. gen. Microbiol. 23, 621.

Sharpe, M. E. \& Shattock, P. M. F. (1952). The serological typing of group D streptococci associated with outbreaks of neonatal diarrhoea. J. gen. Microbiol. 6, 150.

Shatтock, P. M. F. (1949). The streptococci of group D; the serological grouping of Streptococcus bovis and observations on serologically refractory group D strains. J. gen. Microbiol. 3, 80.

Shatтock, P. M. F. (1962). Enterococci. In Chemical and Biological Hazards in Foods. Ed. by J. C. Ayres, A. A. Kraft, H. E. Snyder \& H. W. Walker. Ames, Iowa, U.S.A.: Iowa State University Press.

Skadhauge, K. (1950). Studies on Enterococci. Copenhagen: Einar Munksgaards.

Sмiтн, D. G. (1963). Streptococcus groups $D, N$ and $Q$ : physiological and serological studies. Thesis. University of Reading.

Wheeler, S. M. \& Foley, G. E. (1945a). Studies on the streptococci (enterococci) of Lancefield group D. Am. J. Dis. Child. 70, 207.

WheEler, S. M. \& Foley, G. E. (1945b). A note on the serologic classification of streptococci isolated from subacute bacterial endocarditis. Am. Heart J. 30, 511. 